\title{
Impact of Incremental Surface Soil Depths on Plant Production, Transpiration Ratios, and Nitrogen Mineralization Rates
}

\author{
STEVEN M. LYONS AND GERALD F. GIFFORD
}

\section{Abstract}

From October 1974 to August 1976, a study was conducted to measure how incremental surface soil depths from the pinyonjuniper type affected plant production, plant transpiration rates, and nitrate nitrogen mineralization rates. The treatments were incremental removals of $7.6-\mathrm{cm}$ soil layers to a depth of $30.5 \mathrm{~cm}$. Plant production and transpiration ratios (or water use efficiencies) were measured in greenhouse studies using $A$ gropyron desertorum grown in specified incremental $7.6-\mathrm{cm}$ soil layers taken from five study sites throughout Utah. Significant decreases in plant production and increases in transpiration ratios were measured for all sites at incremental depths beyond $7.6-\mathrm{cm}$. These changes in plant production and transpiration ratios were linearly related to the nitrate nitrogen content of the soils (as determined when the soils were collected for use in the greenhouse). Nitrate mineralization rates were measured for two 6-week periods under field conditions at two sites for each of the $7.6-\mathrm{cm}$ incremental soil layers. Nitrate nitrogen mineralization was linearly correlated with the organic carbon content of the soil. Decreased mineralization rates as measured in the field at both sites were reflected in the significant increases in plant water requirements and decreases in production that were measured in greenhouse studies.

Surface soils may be removed by wind and/or water erosion or through various activities associated with construction and mining. Biotic and hydrologic characteristics of the remaining soil may markedly differ from those of the removed soil and have a significant impact on future rehabilitation efforts.

The amount of water transpired per unit of dry weight production by a given plant species is highly correlated with the fertility of its soil environment, primarily available nitrogen (Briggs and Shantz 1913a, 1913b; Sneva, et al. 1958; Thomas and Osenburg 1959; Viets 1962; Smika et al. 1965; Debreczeni and Debreczeni 1974; Natr and Vee 1974). Vegetation growing on an infertile soil produces less yield for the same amount of water transpired. Debreczeni and Debrec-

\footnotetext{
Authors are graduate research assistant and professor, Rangeland Hydrology, Watershed Science Unit, College of Natural Resources, Utah State University, Logan, 84322. Mr. Lyons is currently hydrologist with the Bureau of Land Management, Montrose, Colorado.

This research was sponsored by the Utah Agricultural Experiment Station and the Office of Water Research and Technology (Grant A-022-Utah), Department of Interior, in cooperation with the Bureau of Land Management. Journal Paper 2377, Utah Agricultural Experiment Station, Logan, 84322.

Manuscript received November 16, 1979.
}

zeni (1974) found a $13.1 \%, 24.0 \%$, and $22.2 \%$ decrease in the transpiration ratio ( $\mathrm{ml}$ water/gm dry matter) when fertilizing with $0.25,0.50$, and $0.75 \mathrm{~g}$ of nitrogen, respectively, using oats grown in pots. No decrease was noted when phosphorus or phosphorus-potassium fertilizers were added. Natr and Vee (1974) also found no significant decrease in transpiration rates due to phosphorus. The only nutrient seemingly responsible for changes in transpiration ratios is nitrogen.

Many investigators have done extensive research on factors affecting ammonification, nitrification, and the effects of the processes on vegetal production (Harmsen and Van Schreven 1955; Fitts et al. 1955; Sneva et al. 1958; Bremmer 1965; Legg et al. 1971; Stanford and Smith 1972). Allison and Sterling (1948), Harmsen and Kolenbrander (1965), Standford and Smith (1972), and Stanford and Epstein (1974) found that the limiting step in nitrogen mineralization is the conversion of organic nitrogen to ammonium $\left(\mathrm{NH}_{4}\right)$ through the process of decomposition by bacteria. The ammonium is then oxidized to form nitrate $\left(\mathrm{NO}_{3}\right)$, which is considered to be available for plant use. The measurement of the nitrogen mineralization rate of a given soil therefore is a measurement of its ammonification rate.

The quantity of soil nitrogen mineralization achieved in a given time depends upon temperature, available water, rate of oxygen replenishment, soil $\mathrm{pH}$, amount and nature of plant residues, and levels of other soil nutrients (Harmsen and Van Schreven 1955). Optimum soil temperatures for nitrification range from $28^{\circ} \mathrm{C}$. to $35^{\circ} \mathrm{C}$. Harmsen and Kolenbrander (1965) recorded almost complete nitrification at temperatures between $0-35^{\circ} \mathrm{C}$. The same researchers also found that even though nitrification ceases at $45^{\circ} \mathrm{C}$. ammonification continues. Highest nitrogen mineralization rates occurred between the soil matric suctions of 0.1 to 0.5 bars, or that range which encompasses the soil water content defined as "field capacity" (Miller and Johnson 1964; Stanford and Epstein 1974). Stanford and Epstein (1974) and Reichman et al. (1966) found a linear relationship between nitrogen mineralization and soil water content. As the matric suction increased from 0.2 to 15 bars, the nitrogen mineralization rate decreased. Robinson (1957) concluded that 
"active nitrification of the natural soil nitrogen stops at a soil mosture level just below the permanent wilting percentage (about 15 bars); however, ammonia nitrogen accumulates substantially."

Haque and Walmsley (1972) and Allison and Sterling (1948) found good correlations between nitrogen mineralization and total nitrogen of the soil. Allison and Sterling obtained a correlation coefficient between nitrogen mineralization and total nitrogen of the soil at 0.809 after 42 days of incubation. They also found that the rate of mineralization decreased with time. The variations in results among investigators have probably been due to differences in microorganism populations, quantity of other nutrients present, and soil moisture levels.

The specific objectives of this study were to determine how plant growth characteristics and water use efficiencies are affected by successive 7.6-cm incremental soil layers of a soil profile and secondly to determine field nitrate nitrogen mineralization rates as a function of successive 7.6-cm layers of a soil profile.

\section{Method and Procedure}

\section{Site Description}

Five study sites were selected throughout Utah, all similar with respect to land management treatments. All sites are within the pinyon-juniper (Pinus spp.-Juniperus spp.) type and all had been chained with debris left in place. The study sites had been seeded several years prior to this study with crested wheatgrass (Agropyron desertorum) and Fairway wheatgrass (A. cristatum).

\section{Blanding Site}

The Blanding site is about $70 \mathrm{~km}$ west of Blanding, Utah, in the N.E. $1 / 4$ of S.W. $1 / 4$ of T38S, R $18 \mathrm{E}$, near Coyote Flat. Its elevation is about $1,981 \mathrm{~m}$ with a 30 -year $(1931-1960)$ average annual precipitation of about $28 \mathrm{~cm}$ per year, of which about $13 \mathrm{~cm}$ falls between May and September. Soils are derived from sandstone-siltstone and are of the Ardic Argiustolls-Typic Argiustrolls association. The texture is sandy loam and the color is red (Gifford 1973). The $\mathrm{pH}$ ranges from 7.7 to 8.1 , with a total nitrogen $\%$ of 0.13 to 0.21
(Table 1). The area was double-chained in the fall of 1967 and broadcast seeded at a rate of $9.2 \mathrm{~kg}$ per hectare.

\section{Brush Creek Site}

Brush Creek is about $21 \mathrm{~km}$ northeast of Vernal, Utah, in the N.E. $1 / 4$ of Section 35 and N.W. $1 / 4$ of Section 36 of T2N, R22E, on the Brush Creek Chaining Project. The site elevation is about 1,730 $\mathrm{m}$. Annual precipitation averages $28 \mathrm{~cm}$, with about $50 \%$ falling from May to September. The soils are from the Typic Torriorthents (Shallow)-Lithic Calciorthids association. The texture is a sandy loam with a pH of about 7.9 to 8.2 and uniformly low nitrogen content of about $0.4 \%$ (Table 1). Age of the chaining project was not determined.

\section{Milford Site}

The Milford site is about $72.4 \mathrm{~km}$ west of Minersville, Utah, in the S. $1 / 2$ of Section $7, \mathrm{~T} 30 \mathrm{~S}, \mathrm{R} 15 \mathrm{~W}$. Its elevation is $2,100 \mathrm{~m}$, and the annual precipitation averages about $36 \mathrm{~cm}$, with $15 \mathrm{~cm}$ occurring from May to September. The soils are from the Xerollic Calciorthids-Xerollic Paleorthids association and have a silt loam to loam texture (Gifford and Tew 1959). The soil pH is slightly lower than the first two sites, ranging from 7.2 to 7.4 . The organic carbon is higher, ranging from 0.7 to $1.7 \%$ (Table 1). This site was double-chained in the fall of 1967 and broadcast seeded to crested wheatgrass.

\section{Huntington Site}

The Huntington site lies about $12 \mathrm{~km}$ up Huntington Canyon, Utah, on top of a small plateau that is about $350 \mathrm{~m}$ south of the Huntington Power Plant in Section 36, T17S, R7E. Site elevation is $2,010 \mathrm{~m}$ and its average annual precipitation is about $40 \mathrm{~cm}$, with about $18 \mathrm{~cm}$ occurring between May and September. The soils are of the Agric Cryoborolls-Pachic Cryoborolls-Cryic Paleborolls association with a sandy loam soil texture. The $\mathrm{pH}$ ranges from 7.8 to 8.0 , with total nitrogen and organic carbon percentages of about 0.19 and 1.7 , respectively.

\section{Dove Creek Site}

The Dove Creek site is approximately $17 \mathrm{~km}$ southwest of Park Vallcy, Utah in N.S. $1 / 2$ of Scction 13, T12N, R 15 W. Its elevation is about $1,675 \mathrm{~m}$. The annual precipitation averages about $28 \mathrm{~cm}$, of which around 11 occur from May through September. The soil is clay loam to loam in texture and and is from the Aridic Calcic

Table 1. Soil analysis of study sites (August 1974).

\begin{tabular}{|c|c|c|c|c|c|c|c|c|c|c|c|}
\hline Site & $\begin{array}{l}\text { Soil } \\
\text { Depth } \\
(\mathrm{cm})\end{array}$ & Texture & $\mathrm{pH}$ & $\begin{array}{c}\mathrm{EC}_{\mathrm{c}} \\
(\mathrm{mmhos} / \mathrm{cm})\end{array}$ & $\begin{array}{c}\text { CEC } \\
(\mathrm{me} / 100 \mathrm{~g})\end{array}$ & $\begin{array}{c}\mathrm{NO}_{3}-\mathrm{N} \\
(\mathrm{ppm})\end{array}$ & $\underset{(\mathrm{ppm})}{\mathrm{P}}$ & $\underset{(\mathrm{ppm})}{\mathrm{K}}$ & $\begin{array}{c}\mathrm{N} \\
(\%)\end{array}$ & $\begin{array}{c}\text { Org. C } \\
(\%)\end{array}$ & $\begin{array}{l}\text { Water-sol } \\
\mathrm{Na} \\
(\mathrm{me} / \mathrm{l00 \textrm {g }})\end{array}$ \\
\hline Blanding & $\begin{array}{r}0-7.6 \\
7.6-15.2 \\
15.2-22.9 \\
22.8-30.5\end{array}$ & $\begin{array}{l}\text { Sandy } \\
\text { Loam }\end{array}$ & $\begin{array}{l}7.7 \\
7.9 \\
8.1 \\
8.1\end{array}$ & $\begin{array}{l}0.3 \\
0.4 \\
0.3 \\
0.3\end{array}$ & $\begin{array}{l}10.6 \\
12.3 \\
14.0 \\
12.7\end{array}$ & $\begin{array}{l}0.7 \\
0.1 \\
0.4 \\
0.4\end{array}$ & $\begin{array}{l}7.7 \\
2.3 \\
1.7 \\
1.7\end{array}$ & $\begin{array}{r}164 \\
143 \\
94 \\
73\end{array}$ & $\begin{array}{l}0.21 \\
0.18 \\
0.15 \\
0.13\end{array}$ & $\begin{array}{l}0.4 \\
0.7 \\
<0.1 \\
0.8\end{array}$ & $\begin{array}{l}<0.1 \\
<0.1 \\
<0.1\end{array}$ \\
\hline $\begin{array}{l}\text { Brush } \\
\text { Creek }\end{array}$ & $\begin{array}{r}0-7.6 \\
7.6-15.2 \\
15.2-22.9 \\
22.8-30.5\end{array}$ & $\begin{array}{l}\text { Sandy } \\
\text { Loam }\end{array}$ & $\begin{array}{l}7.9 \\
8.0 \\
8.1 \\
8.2\end{array}$ & $\begin{array}{l}0.3 \\
0.3 \\
0.3 \\
0.3\end{array}$ & $\begin{array}{l}7.1 \\
6.8 \\
6.8 \\
5.4\end{array}$ & $\begin{array}{r}1.0 \\
0.1 \\
<0.1 \\
<0.1\end{array}$ & $\begin{array}{l}5.7 \\
2.9 \\
2.5 \\
2.3\end{array}$ & $\begin{array}{r}171 \\
104 \\
84 \\
71\end{array}$ & $\begin{array}{l}0.08 \\
0.06 \\
0.06 \\
0.06\end{array}$ & $\begin{array}{l}0.4 \\
0.4 \\
0.4 \\
0.3\end{array}$ & $\begin{array}{l}<0.1 \\
<0.1 \\
<0.1 \\
<0.1\end{array}$ \\
\hline Milford & $\begin{array}{rr}0 & 7.6 \\
7.6 & -15.2 \\
15.2 & -22.9 \\
22.8 & -30.5\end{array}$ & $\begin{array}{c}\text { Sandy Loam } \\
\text { to } \\
\text { Loam }\end{array}$ & $\begin{array}{l}7.2 \\
7.2 \\
7.2 \\
7.4\end{array}$ & $\begin{array}{l}0.4 \\
0.4 \\
0.5 \\
0.5\end{array}$ & $\begin{array}{l}17.3 \\
19.9 \\
20.7 \\
18.2\end{array}$ & $\begin{array}{l}1.7 \\
0.6 \\
0.6 \\
0.6\end{array}$ & $\begin{array}{r}11.0 \\
5.2 \\
4.2 \\
3.7\end{array}$ & $\begin{array}{l}>480 \\
<480 \\
>480 \\
>480\end{array}$ & $\begin{array}{l}0.14 \\
0.10 \\
0.11 \\
0.07\end{array}$ & $\begin{array}{l}1.7 \\
1.2 \\
0.9 \\
0.7\end{array}$ & $\begin{array}{l}0.1 \\
0.1 \\
0.1 \\
0.1\end{array}$ \\
\hline Huntington & $\begin{array}{r}0-7.6 \\
7.6-15.2 \\
15.2-22.9 \\
22.8-30.5\end{array}$ & $\begin{array}{l}\text { Sandy } \\
\text { Loam }\end{array}$ & $\begin{array}{l}7.8 \\
7.8 \\
7.9 \\
8.0\end{array}$ & $\begin{array}{l}0.5 \\
0.4 \\
0.4 \\
0.3\end{array}$ & $\begin{array}{r}9.0 \\
12.3 \\
13.6 \\
13.2\end{array}$ & $\begin{array}{l}3.5 \\
1.2 \\
0.9 \\
1.6\end{array}$ & $\begin{array}{r}16.0 \\
5.0 \\
5.5 \\
4.9\end{array}$ & $\begin{array}{l}371 \\
297 \\
212 \\
177\end{array}$ & $\begin{array}{l}0.20 \\
0.17 \\
0.19 \\
0.19\end{array}$ & $\begin{array}{l}1.7 \\
1.7 \\
1.9 \\
1.7\end{array}$ & $\begin{array}{r}<0.1 \\
0.1 \\
0.1 \\
<0.1\end{array}$ \\
\hline Dove Creek & $\begin{array}{r}0-7.6 \\
7.6-15.2 \\
15.2-22.9 \\
22.8-30.5\end{array}$ & $\begin{array}{c}\text { Clay Loam } \\
\text { to } \\
\text { Loam }\end{array}$ & $\begin{array}{l}7.8 \\
7.9 \\
8.0 \\
8.0\end{array}$ & $\begin{array}{l}0.3 \\
0.3 \\
0.4 \\
0.4\end{array}$ & $\begin{array}{l}17.8 \\
17.8 \\
17.8 \\
16.3\end{array}$ & $\begin{array}{l}4.9 \\
1.8 \\
1.5 \\
1.3\end{array}$ & $\begin{array}{r}22.0 \\
9.7 \\
5.7 \\
5.8\end{array}$ & $\begin{array}{r}>480 \\
398 \\
417 \\
342\end{array}$ & $\begin{array}{l}0.26 \\
0.15 \\
0.13 \\
0.15\end{array}$ & $\begin{array}{l}2.4 \\
1.5 \\
1.4 \\
1.3\end{array}$ & $\begin{array}{l}0.1 \\
0.1 \\
0.1 \\
0.1\end{array}$ \\
\hline
\end{tabular}


Arigixerolls-Aridic Petrocalcic Palexerolls association.

\section{Plant Production}

During August and September of 1974, random soil samples were collected at four different depths $(0-7.6 \mathrm{~cm}, 7.6-15.2 \mathrm{~cm}$, $15.2-22.9 \mathrm{~cm}$, and $22.9-30.5 \mathrm{~cm}$ ) over each of the five study site areas. The samples were sieved through a 16-mesh screen to remove rocks and plant root material, and subsamples were analyzed for the parameters given in Table 1. The soil samples were then dried and weighed and put into 1-gallon cardboard pots at a rate of $6.4 \mathrm{~kg}$ per pot. Ten replications of each depth for each of the five sites were used, and each pot was planted with four crested wheatgrass (Agropyron desertorum) seeds. At the end of a 3-week germination period, each pot was thinned to two plants per pot.

One growth period was defined as 84 days. Incandescent lights were used to ensure 18 days of "daylight"; air temperature was maintained at an average minimum of $20^{\circ} \mathrm{C}$, and sufficient amounts of distilled water were added to avoid water stress. At the end of each 84-day growth period, the plants were clipped at $2.5 \mathrm{~cm}$ above the soil surface, oven dried, and weighed to determine aboveground production. Measurements were made over two 84day growth periods, and each growth period was treated separately.

\section{Transpiration Ratios}

Water use efficiency or transpiration ratio was defined as the weight (grams) of the total amount of water transpired per gram of above-ground biomass produced. Blanding and Milford were selected as representative sites and used for the transpiration ratio determinations. Six replications were made for each of the four depths at both (Blanding and Milford) sites.

The surface soils were sealed in each pot with two layers of heavy duty aluminum foil and caulking compound. The moisture contents of the pots were maintained below field capacity ( $1 / 3$ atmosphere) but above the permanent wilting point ( 15 atmospheres) based on total pot weight. A careful record was maintained on the amount of distilled water added to each pot during an 84-day growth period. The crested wheatgrass plants used in these water efficiency studies had previously been utilized in our production study. The water-use data were combined with the dry matter weights obtained at the end of the 84-day growth period and used to calculate the water use efficiencies or transpiration ratios.

\section{Nitrogen Mineralization Rate}

Our procedures were basically the same as those prescribed by Stanford and Smith (1972). The primary differences were: (1) incubation was conducted in the field under natural temperature variations, (2) $\mathrm{N}$-minus nutrient solutions were not added to soils, and (3) the soil samples themselves were analyzed for nitrate nitrogen content, not leachates from soil samples.

Soil samples were collected and processed in the same manner as the soils used in the plant production determinations. The soil was mixed with exfoliated vermiculite at a rate of $1: 1 / 3$ by volume. Approximately 15 to $20 \mathrm{~g}$ of soil mixture were placed into leach tubes (Fig. 1) through which water could percolate. The soil within the tubes was wetted with distilled water and incubated at $35^{\circ} \mathrm{C}$ for 2 weeks so that the microbial populations could reach equilibrium with the soil. Mineral nitrogen was removed by leaching with $110 \mathrm{ml}$ of $0.01 \mathrm{~m} \mathrm{CaC}_{2}$ in 5 to $10 \mathrm{ml}$ increments followed by $25 \mathrm{ml}$ of distilled water. The soil cores within the leach tubes were allowed to drain to field capacity. The ends of each tube were stopped with one-hole stoppers to prevent excessive water loss and placed into the ground at each study site so that the top of the soil core was level with the ground surface. At the end of the prescribed 6-week incubation period, the soil was removed from the tubes, air dried in the summer sun and analyzed for nitrate nitrogen.

Vermiculite was added to the soil to prevent soil compaction and encourage a more rapid leaching process (Stanford and Hanway 1955). Glass wool pads at both ends of the $7.6 \mathrm{~cm}$ soil core helped hold the soil in place and prevent dispersion of soil when adding

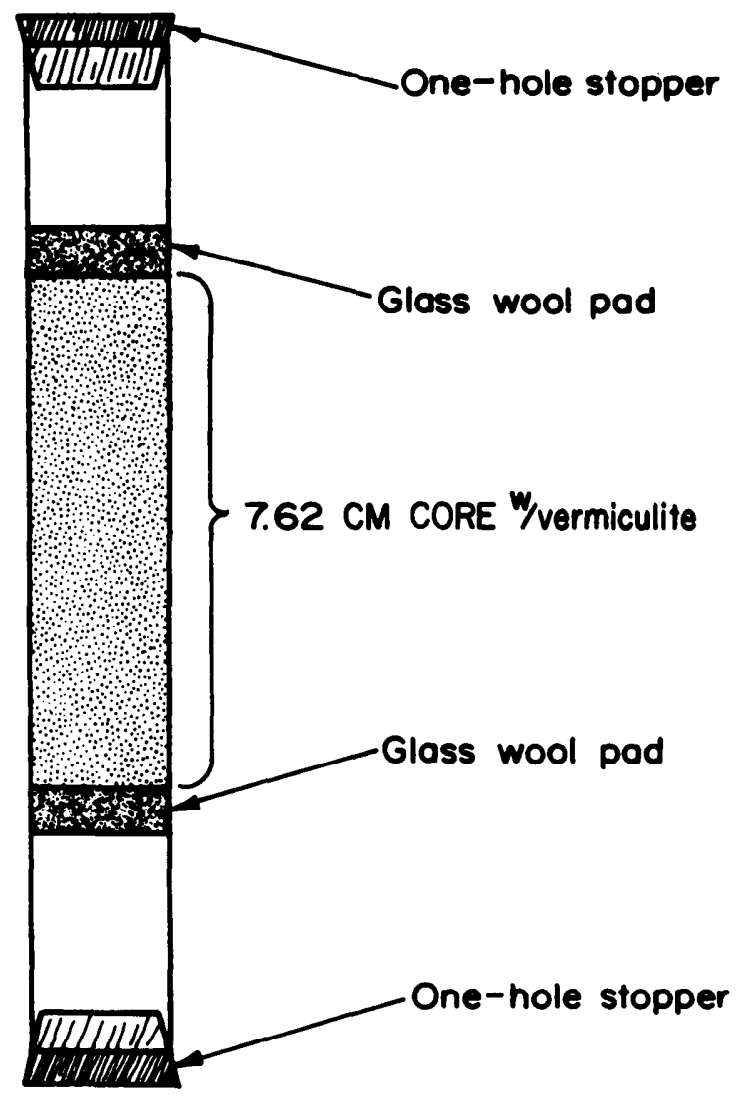

Fig. 1. Leach tube with soil core.

leaching fluids. The upper half of each tube was painted white to prevent any "greenhouse effect" within the tube.

Nitrogen mineralization rates were for soils from the Blanding and Milford sites only. A total of 20 replications for each of the four depths for each site were conducted, half of the replications being completed during late summer of 1975 and the rest during early summer of 1976.

\section{Results and Discussion}

\section{Plant Production}

The analysis of variance for plant production data indicated a significant harvest by date by site treatment-depth interaction. Significant differences between harvest dates had been expected because of nutrient depletion and aging of plant species. Within the three-way interaction, the site by treatment-depth interaction was of particular interest (Fig. 2). This interaction indicated a significant decrease in production for all sites on soils involving the $7.6-$ to $15.2-\mathrm{cm}$ layers as compared with production on the surface $7.6-\mathrm{cm}$ layer. Production continued to decrease as a function of depth only on soils from the Dove Creek and Milford sites, and then only to a depth of $22.9 \mathrm{~cm}$.

Initial laboratory soil analyses (Table 1) revealed major differences in phosphorus and nitrate nitrogen nutrient contents among the various soil depths at nearly all the study sites. Both nitrogen and phosphorus contents were highly correlated (at the $95 \%$ level) with plant production (Fig. 3). However, Natr and Vee (1974) found no significant decrease in growth processes due to deficiencies in phosphorus content. Nitrogen and phosphorus are both mineralized from the unavailable forms found in organic matter to available forms for plant use through associated 


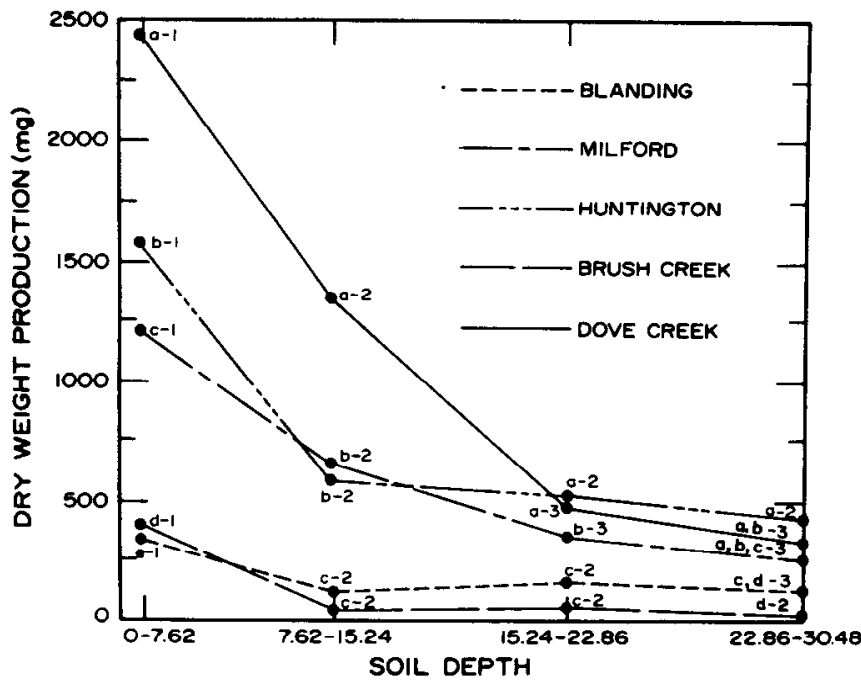

Fig. 2. Plant production of the four subsoil treatments and surface control. Data pooled over two time periods. Lower case letters indicate significant differences among locations within a depth and numbers indicate significant differences among depths within a location at .05 level of probability.

processes that occur in given proportions to one another. This accounts for the apparent correlation of both nutrient species. It appears that the variations in available nitrogen among study sites and treatment depths account for the site by treatment-depth interaction.

\section{Transpiration Ratios}

Results of this project segment indicated significant differences in transpiration ratios for treatment depths and for study sites. Figure 4 graphically illustrates differences in transpiration ratios with soil depth as pooled over both sites. Pooled over all treatment depths at both sites the average transpiration ratio for the Blanding site was 4,024 and for the Milford site was 3,214. As fertility decreased, the

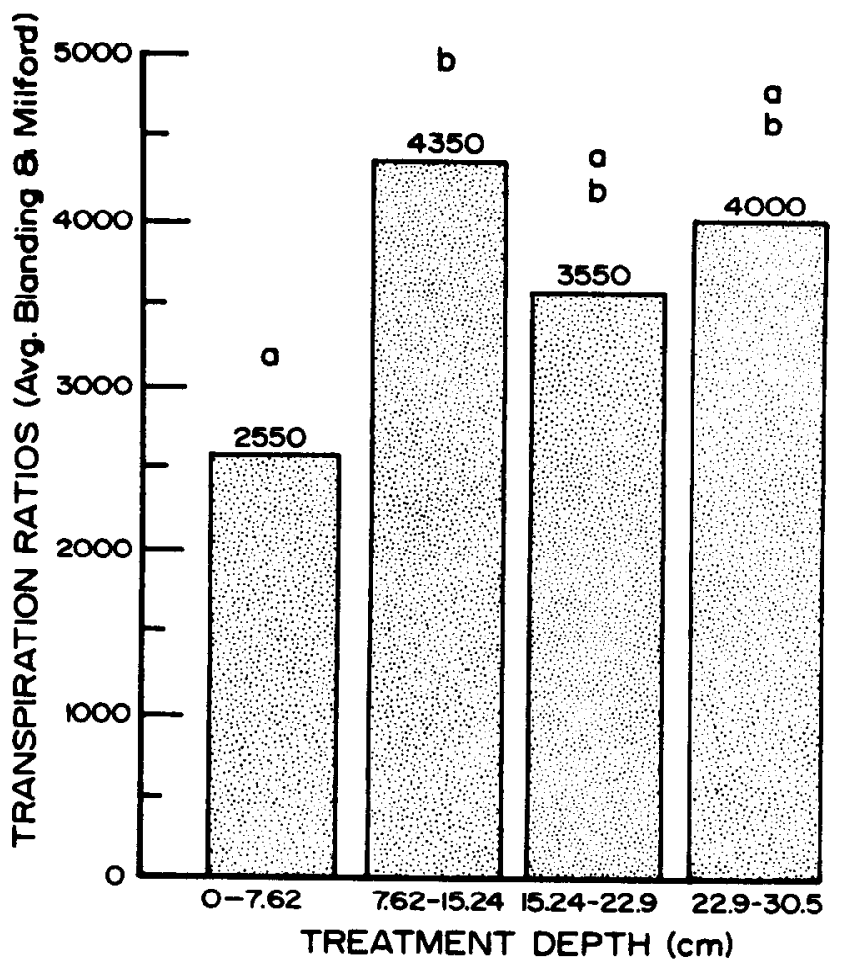

Fig. 4. Transpiration ratios for the four treatment depths as pooled over both locations. Any bars with the same subscript are not significantly different at the .05 level of probability.

transpiration ratio increased, meaning that more water was being required per gram of plant material produced.

Transpiration ratios appear to be highly correlated with soil nitrate nitrogen (Fig. 5). Correlation coefficients of -0.89 and -0.94 were obtained for the Blanding nd Milford sites, respectively, both of which are significant at the $95 \%$ level.

The reason for the increased consumption of water by
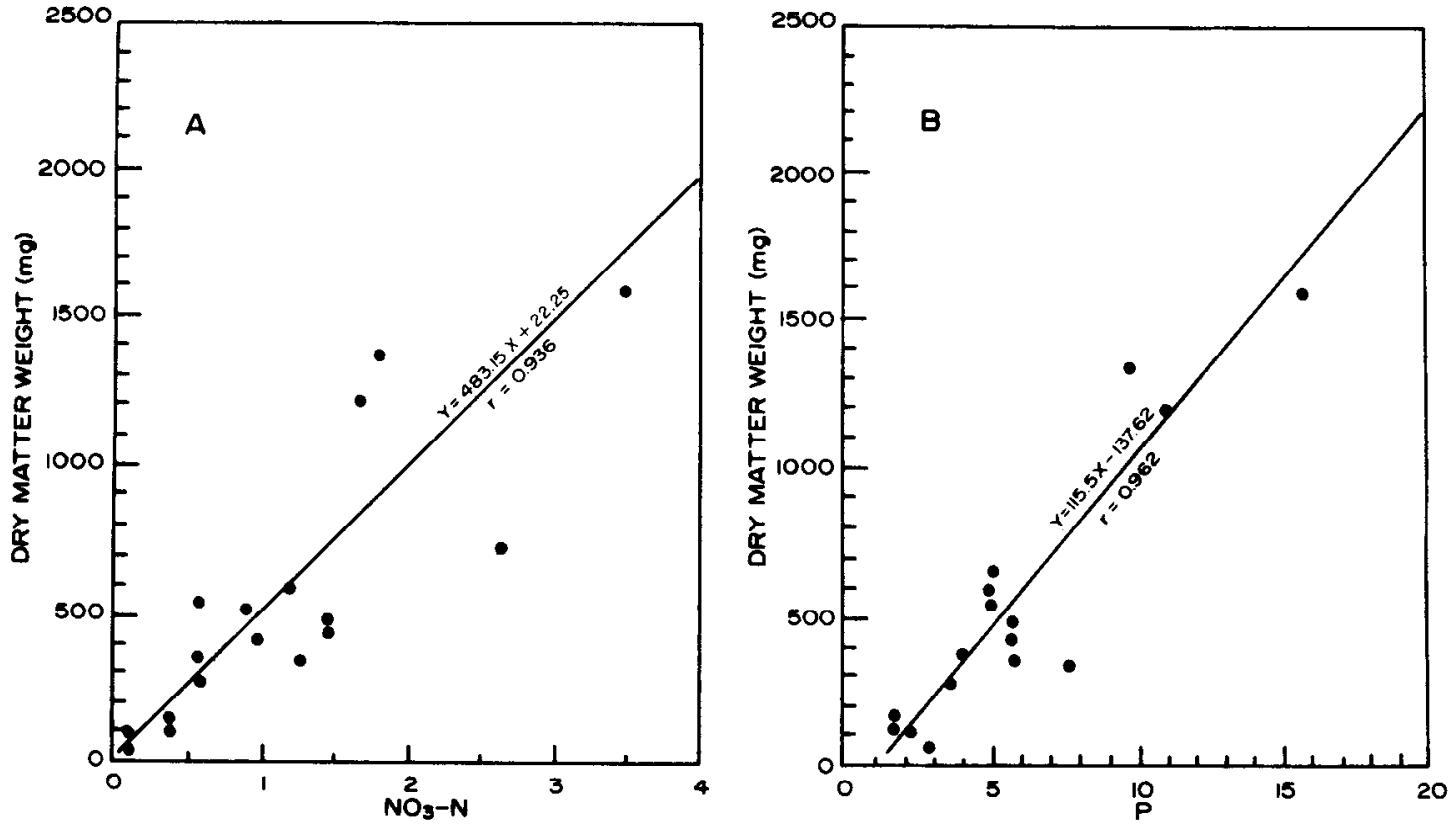

NUTRIENT CONCENTRATIONS (ppm)

Fig. 3. Relationship of plant production to nitrate nitrogen and phosphorus concentration of the soil. Both regressions are significant at .05 level of probability. 

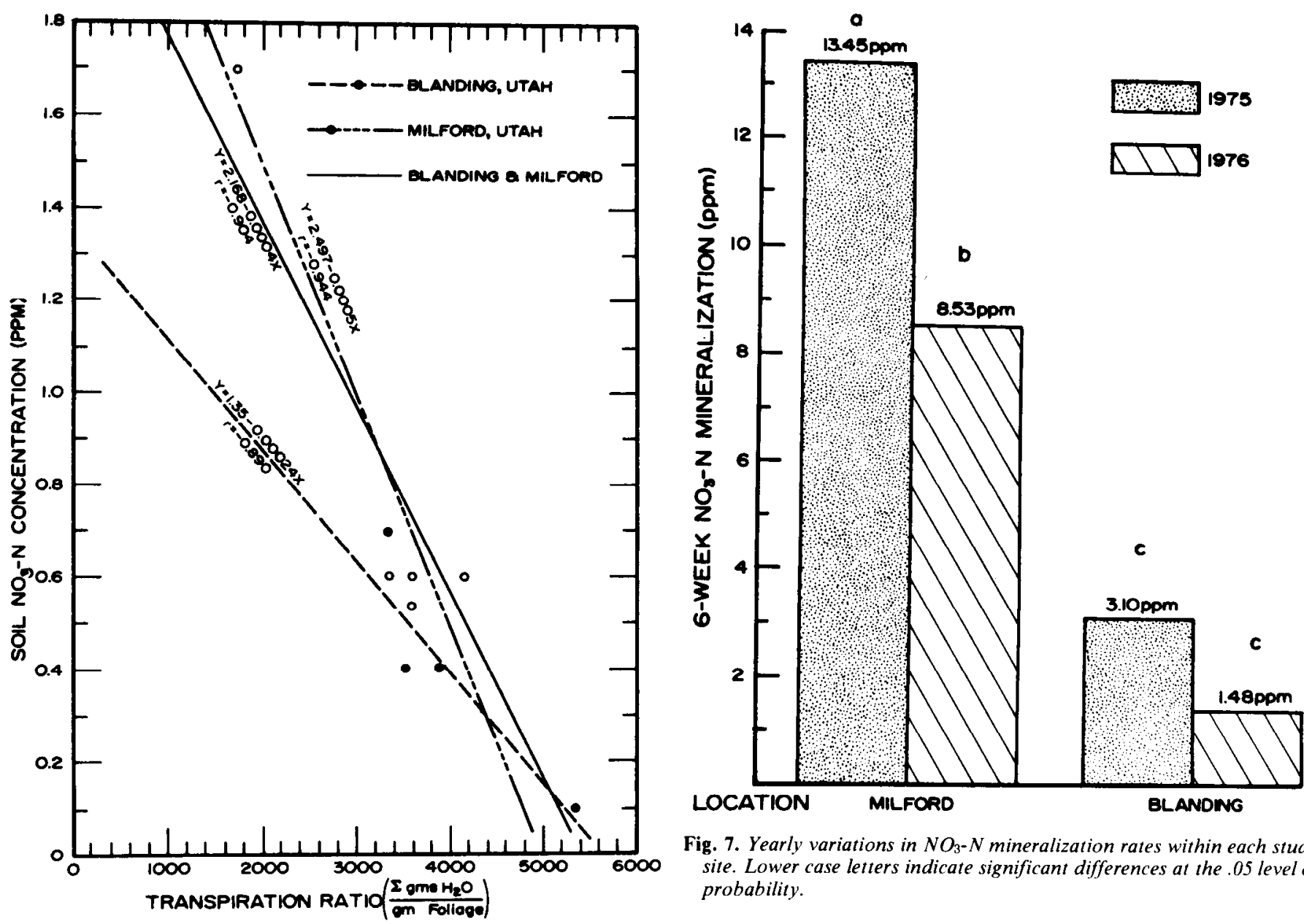

Fig. 5. Correlation between transpiration ratios and nitrate nitrogen concentration. Regressions are significant at .05 level of probability.
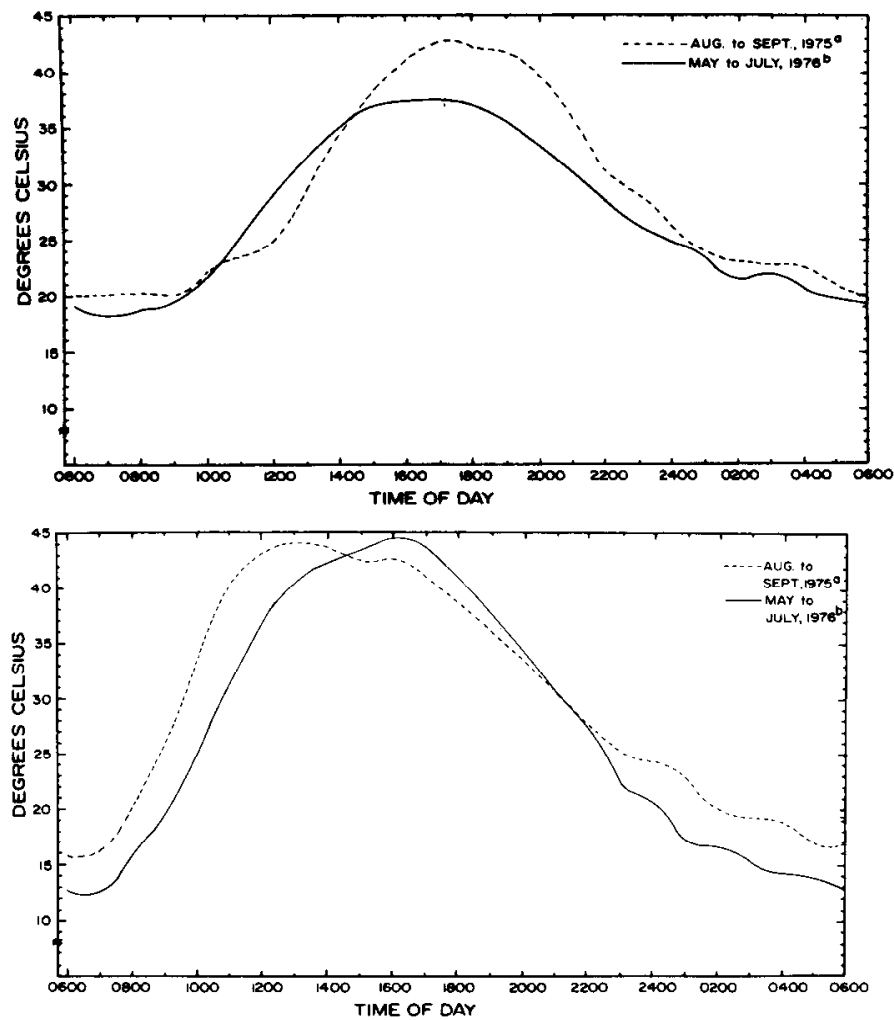

Fig. 7. Yearly variations in $\mathrm{NO}_{3}-\mathrm{N}$ mineralization rates within each study site. Lower case letters indicate significant differences at the .05 level of probability.

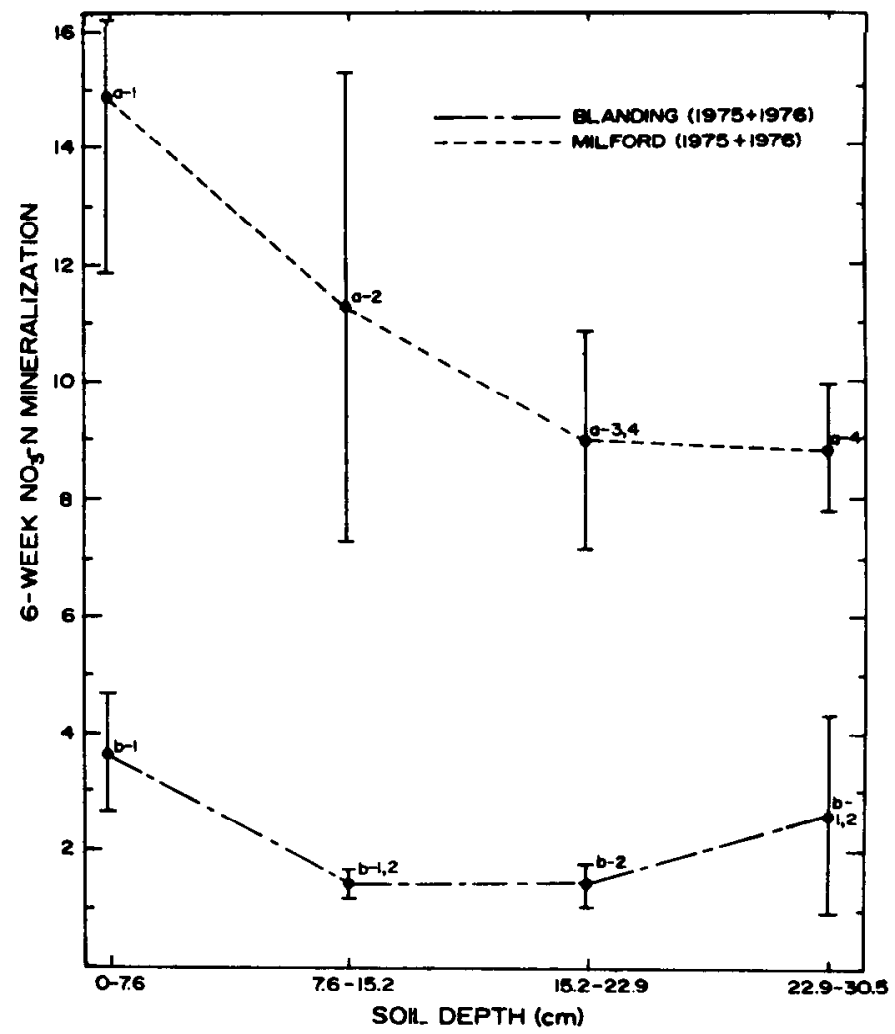

Fig. 8. Average $\mathrm{NO}_{3}-\mathrm{N}$ mineralization rates for each of the $7.6 \mathrm{~cm}$ layers of soil profile. Lower case letters indicate significant differences between locations within a given depth increment and numbers indicate significant differences among depths within a location at the .05 level of probability.

Fig. 6. Top: average daily soil temperature distribution at a depth of $3 \mathrm{~cm}$ for the Blanding site during 1975 and 1976. Bottom: same for the Milford sile during 1975 and 1976. 

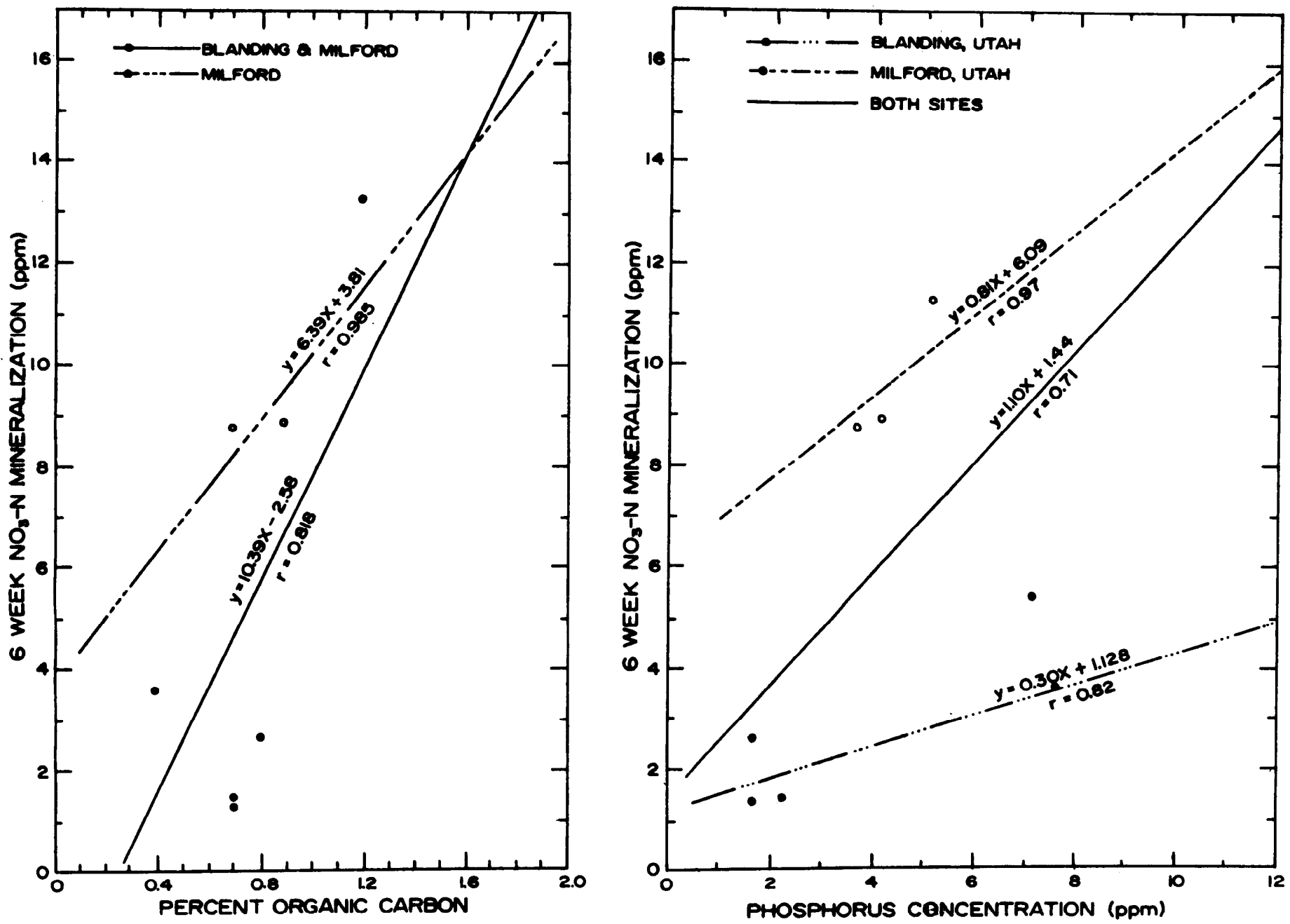

Fig. 9. Correlation between $\mathrm{NO}_{3}-\mathrm{N}$ mineralization and percent organic carbon (left) and phosphorus (right) in the soil. Regressions are significant at .05 level of probability.

plants grown in nutrient-deficient soils is not fully understood. Tradition would dictate that transpiration is controlled by physical parameters when water is not a limiting factor. Debreczeni and Debreczeni (1974) have shown that nitrogen is the primary nutrient affecting transpiration, as well as photosynthesis. The Debreczenis

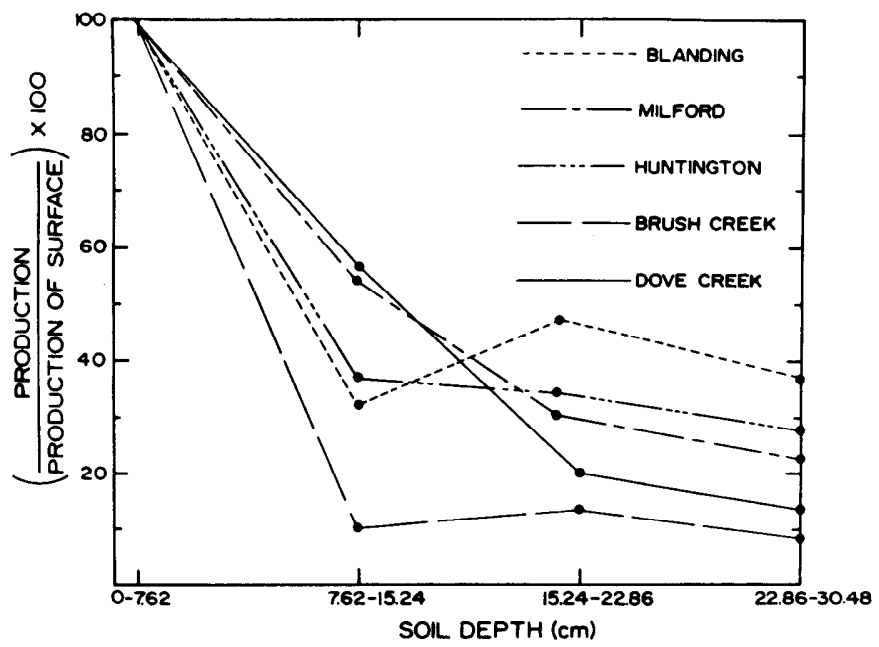

Fig. 10. Percent of production from subsoils as compared to production of the surface control.

theorized that the transpiration process of plants in nitrogen-deficient soils may increase as a way to cause increases in water flow toward the roots, which in turn would facilitate the movement of ions to the root surfaces.

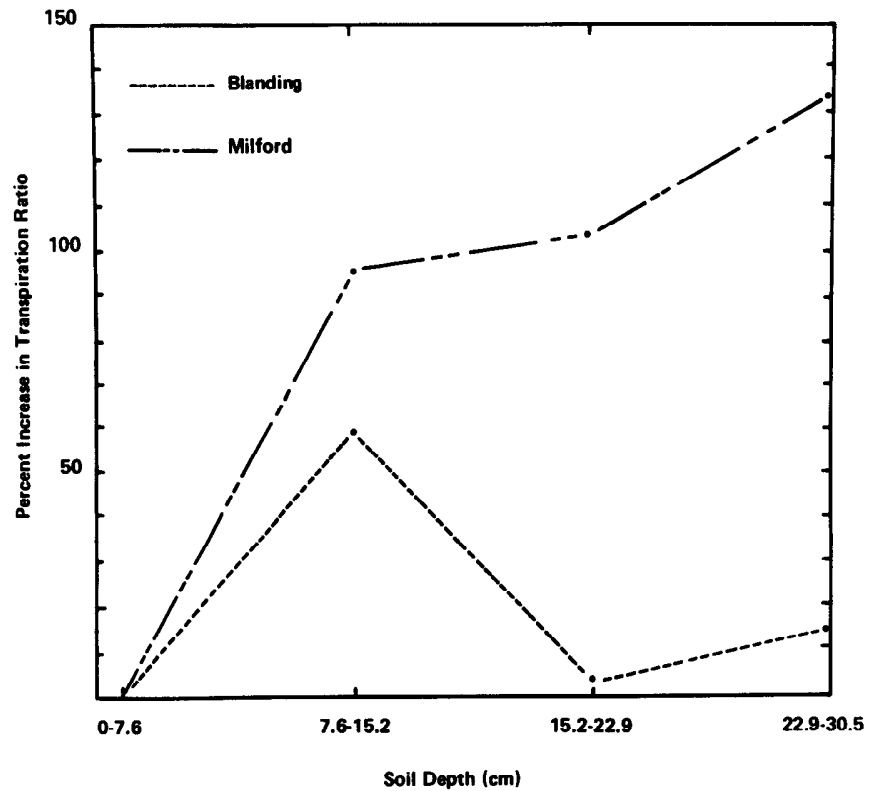

Fig. 11. Percent increase in transpiration ratios as a function of soil depth. 
BLANDING

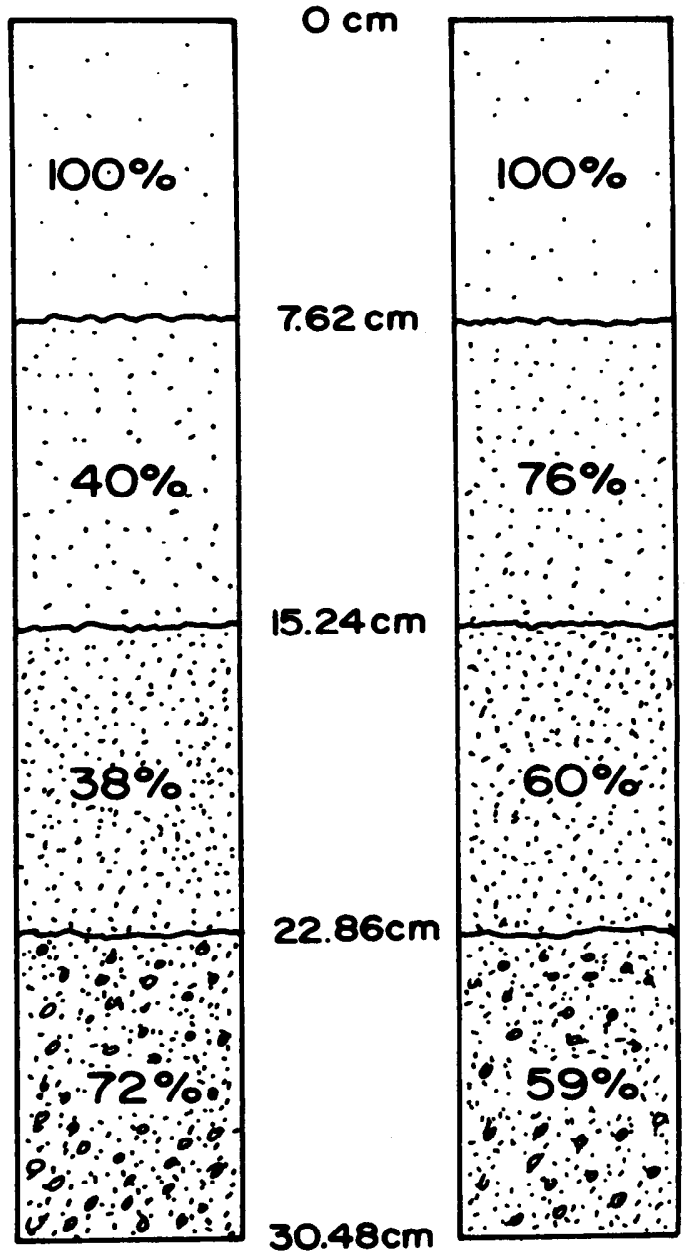

Fig. 12. Schematic profiles showing relative $\mathrm{NO}_{3}-\mathrm{N}$ mineralization of the subsoils as compared to surface soils of the two study sites.

\section{Nitrogen Mineralization}

Analysis of our nitrogen data revealed a significant year by site by treatment-depth interaction. We attribute the significant differences in the mineralization rates between years primarily to concomitant variations in average soil temperatures (fig. 6). In the second season, soil temperatures averaged lower than in the first season, which corresponds to the variations in nitrate nitrogen mineralization rates illustrated in Figure 7.

The site by treatment-depth interaction was also significant (Fig. 8). Good correlations were obtained at the 95\% level (especially for the Milford site) when comparing the amount of nitrate nitrogen mineralized over a 6-week period with both the percent of organic carbon and the phosophorus concentration (Fig. 9). Correlations between the entities that add to soil fertility, including organic carbon, phosphorus, total nitrogen, etc., were expected to be high because of the effects of these factors on the microbial populations that are responsible for the mineralization processes. The correlation coefficient for percent organic carbon for the Blanding site (not shown in Fig. 9) was 0.67 , significant at only the $80 \%$ level. The correlation coefficients obtained for the average of the sites illustrated in Figure 9 were significant at the $95 \%$ level.

\section{Summary and Conclusions}

Our results indicate that significant decreases in plant production and significant increases in the amount of water required to grow each gram of vegetation occur when the top $7.6 \mathrm{~cm}$ layer of surface soil is removed. Plant production on the better sites decreased by about $45 \%$ and by 65 to $85 \%$ on the less fertile sites (Fig. 10). The amount of water required to produce a gram of above-ground biomass increased by $60-95 \%$ when the top $7.6 \mathrm{~cm}$ soil layer was removed (Fig. 11). In semiarid areas where soil moisture is usually the limiting factor during the growing season, such an increase in water requirements could be very significant to the survival of the existing plant community.

Our nitrogen mineralization values were significantly lower than those reported by other investigators, who measurcd nitrogen mineralization "potentials," optimizing all of the known variables involved in the mineralization process. The values obtained in this study were nitrogen mineralization rates of natural soils under natural environmental conditions.

The nitrogen mineralization results varied between the Blanding Milford sites (Fig. 12). Only the third incremental soil layer (15.2-cm to 22.9-cm layer) at the Blanding site gave significantly different results than did the surface layer. Because concentrations of organic carbon are greater in subsoils than in surface soils, subsoil layers have a greater potential to mineralize more nitrate nitrogen than does a surface layer. Because of the lower fertility in our subsoils, however, the microbial populations necessary to achieve this potential evidently did not exist. The end result was a nonsignificant decrease with depth in nitrogen mineralization rates at Blanding. The Milford site showed a significant decrease in mineralization rates between the surface layer and the second incremental layer, and between the second and third incremental layers.

\section{Literature Cited}

Allison, F.E., and L.D. Sterling. 1948. Nitrate formation from soil organic matter in relation to total nitrogen and cropping practices. Soil Sci. 67: 239-252.

Bremmer, J.M. 1965. Nitrogen availability indexes. In: C.A. Black (ed.) Soil Nitrogen. Agron. 10: 1324-1345.

Briggs, L.J., and H.L. Shanta. 1913a. The water requirements of plants: I. Investigations in the Great Plains in 1910 and 1911. U.S. Dep. Agr., Plant Ind. Bur. No. 284.

Briggs, L.J., and H.L. Shantz. 1913b. The water requirements of plants: II. A review of the literature. U.S. Dep. Agr., Plant Ind. Bur. No. 285.

Debreczeni, B., and K. Debreczeni. 1974. Relationships between mineral nutrition and transpiration of plants. Agro. es. Talajtan 23: 65-67.

Fitts, J.W., W.V. Bartholomew, and H. Heidel. 1955. Predicting nitrogen fertilizer needs of lowa soils: I. Evaluation and control of factors in nitrate production and analysis. Soil Sci. Soc. Amer. Proc. 19: 69-73.

Gifford, G.F., and R.K. Tew. 1959. Evaluating rangeland water quality with small plot infiltrometers. J. Soil and Water Conserv. 24: 65-67.

Gifford, G.F. 1973. Runoff and sediment yields from runoff plots on chained pinyon-juniper sites in Utah. J. Range Manage. 26: 440-443.

Haque, I., and D. Walmsley. 1972. Incubation studies on mineralization of organic sulphur and organic nitrogen. Plant and Soil 37: 255-264.

Harmsen, G.W., and D.A. Van Schreven. 1955. Mineralization of organic nitrogen in soil. Adv. in Agron. 7: 299-398.

Harmsen, G.W., and G.J. Kolenbrander. 1965. Soil inorga nic nitrogen. In: W.V. Bartholomew and F.E. Clark (ed.) Soil Nitrogen. Agron. 10:43-92.

Legg, J.O., F.W. Chichester, G. Stanford, and W.H. DeMar. 1971. Incorporation of ${ }^{15} \mathrm{~N}$-tagged mineral nitrogen into stable forms of soil organic nitrogen. Soil Sci. Soc. Amer. Proc. 35: 273-276.

Miller, R.D., and D.P. Johnson. 1964. Effects of soil tension on carbon dioxide evoluation, nitrification, and nitrogen mineralization. Soil Sci. Soc. of Amer. Proc. 28: 644-647. 
Natr, L. and V.V. Vee. 1974. The effect of nitrogen and phosphorus deficiency on photosynthesis, transpiration, and diffusion resistance of young plants. Scientia Agriculture Bohemslovaca (Cze.). Volume 6 (XXIII).

Reichmann, G.A., D.L. Grunes, F.G. Viets, Jr. 1966. Effects of soil moisture on ammonification and nitrification in two northern plains soils. Soil Sci. Soc. of Amer. Proc. 30:363-366.

Robinson, J.B.D. 1957. The critical relationship between soil moisture content in the region of wilting point and the mineralization of natural soil nitrogen. J. of Agr. Sci. 49: 100-105.

Smika, D.E., H.J. Haas, and J.F. Power. 1965. Effects of moisture and nitrogen fertilzer on growth and water use by native grass. Agron. J. 57: 483-486.

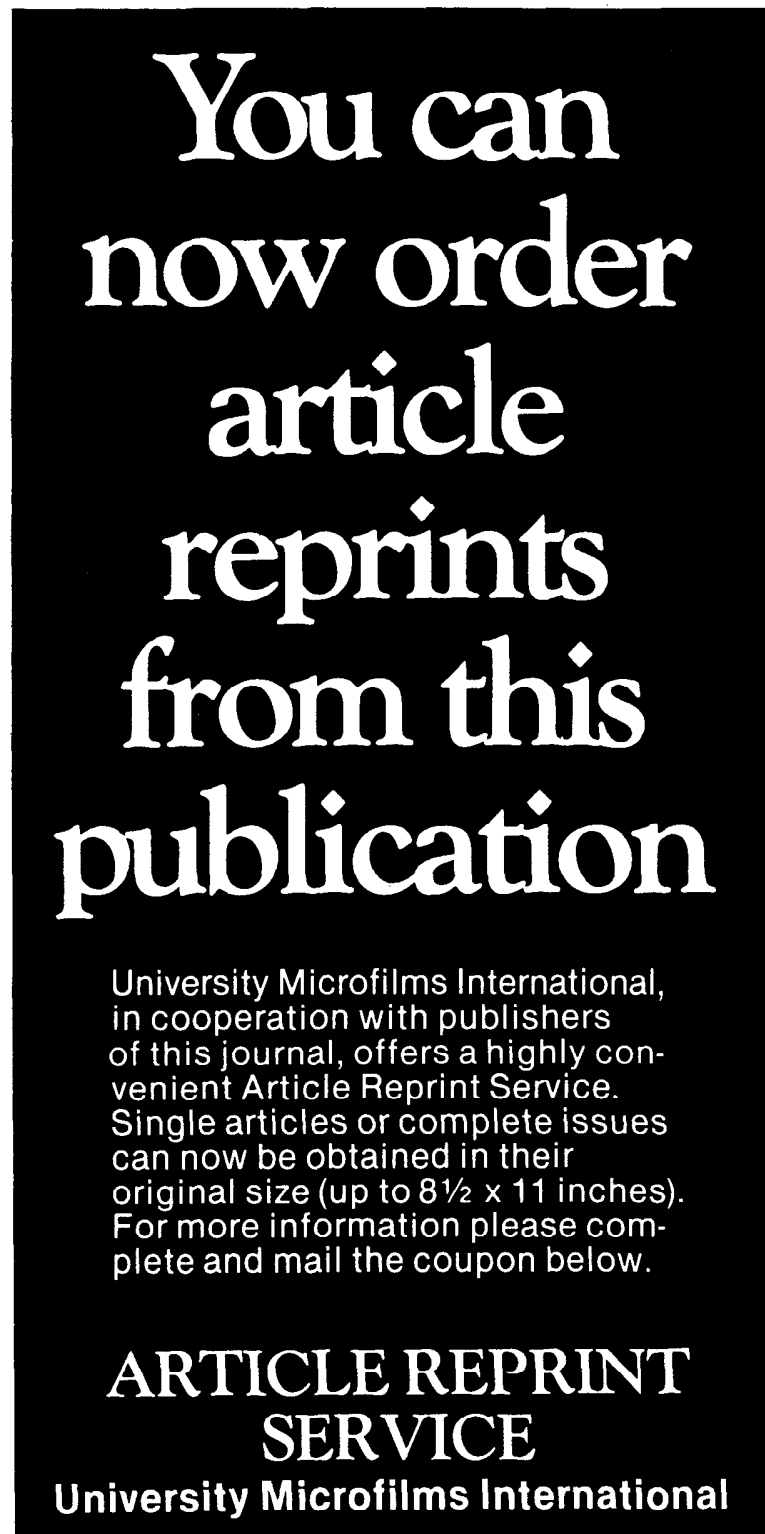

$\square Y E S$ ! I would like to know more about the Article Reprint Service. Please send me full details on how I can order. $\square$ Please include catalogue of available titles.

Name Title

Institution/Company

Department

Address

City State Zip

Mail to: University Microfilms International Article Reprint Service 300 North Zeeb Road

Ann Arbor, Michigan 48106
Sneva, F.A., D.N. Hyder, and C.S. Cooper. 1958. The influence of ammonium nitrate on the growth and yield of crested wheatgrass on the Oregon high desert. Agron. J. 50: 40-44.

Stanford, G., and J. Hanway. 1955. Predicting nitrogen fertilizer needs of Iowa soils. II. A simplified technique for determining relative nitrate production in soil. Soil Sci. Soc. Amer. Proc. 19: 74-77.

Stanford, G., and S.J. Smith. 1972. Nitrogen mineralization potentials of soils. Soil Sci. Soc. Amer. Proc. 36: 465-472.

Stanford, G., and E. Epstein. 1974. Nitrogen mineralization-Water relations in soils. Soil Sci. Soc. Amer. Proc. 38: 103-106.

Thomas, J.R., and O. Osenburg. 1959. Effect of manure, nitrogen, phosphorus, and climatic factors on the production and quality of bromegrass-crested wheatgrass hay. Agron. J. 51: 63-66.

Viets, F.G., Jr. 1962. Fertilizers and the efficient use of water. Advances in Agron. 14: 223-264.

\section{SRM Publications}

Rangeland Entomology @ \$2.75 Quotable Range Quotes @ \$.75

Proceedings: First International Rangeland Congress@\$72.00.

Rangeland Reference Areas @ $\$ 2.00$.

Glossary of Terms@ @1.50 ...........

Jornada Experimental Range @\$2.50.

Proceedings of U.S./Australia Workshops: Arid Shrublands@\$3.50

Rangeland Ecosystem Evaluation and Management @\$8.00 ......................

Symposium on Resources for Beef Cattle Production@\$3.50

Rangeland Plant Physiology @\$14.50.

Special Management Needs of Alpine Ecosystems $@ \$ 4.50$

Index for JRM Vol. 1-10@\$1.00..

Index for JRM Vol. 10-20@\$1.00 ...

Set of both Indices@\$2.00...

Abstract of Papers Presented at the First International Rangeland Congress @ \$3.00 ...

Back issues JRM (if available): Used copies @ \$1.50 --; New @ \$3.00-_...............

JRM Vol. 31 to current @\$4.66.

Abstracts of papers presented at SRM Annual Meetings available for the years shown; please indicate the number of copies wanted of each issue.

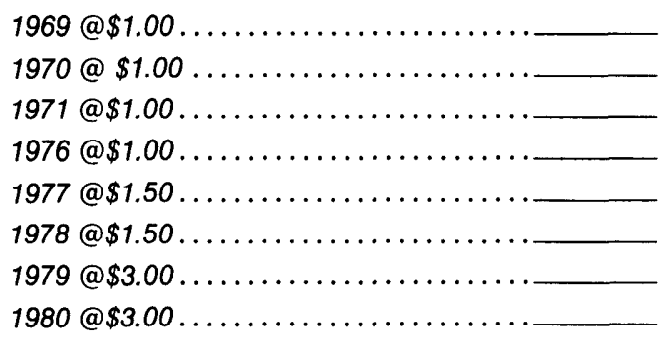

Total cost of all books $\$$

\section{(U.S. currency only)}

Name

Address

City State Zip 